\title{
OPEN Acute invariant NKT cell activation triggers an immune response that drives prominent changes in iron homeostasis
}

\begin{abstract}
Hua Huang ${ }^{1,2}$, Vanessa Zuzarte-Luis ${ }^{3}$, Gabriela Fragoso ${ }^{1}$, Annie Calvé ${ }^{1}$, Tuan Anh Hoang ${ }^{1,2,7}$, Manon Oliero ${ }^{1,4}$, Geneviève Chabot-Roy ${ }^{5}$, Victor Mullins-Dansereau ${ }^{1,4}$, Sylvie Lesage ${ }^{4,5}$ \& Manuela M. Santos ${ }^{1,2,6 凶}$

Iron homeostasis is an essential biological process that ensures the tissue distribution of iron for various cellular processes. As the major producer of hepcidin, the liver is central to the regulation of iron metabolism. The liver is also home to many immune cells, which upon activation may greatly impact iron metabolism. Here, we focus on the role of invariant natural killer T (iNKT) cells, a subset of Tymphocytes that, in mice, is most abundant in the liver. Activation of iNKT cells with the prototypical glycosphingolipid antigen, $\alpha$-galactosylceramide, resulted in immune cell proliferation and biphasic changes in iron metabolism. This involved an early phase characterized by hypoferremia, hepcidin induction and ferroportin suppression, and a second phase associated with strong suppression of hepcidin despite elevated levels of circulating and tissue iron. We further show that these changes in iron metabolism are fully dependent on iNKT cell activation. Finally, we demonstrate that the biphasic regulation of hepcidin is independent of NK and Kupffer cells, and is initially driven by the STAT3 inflammatory pathway, whereas the second phase is regulated by repression of the BMP/SMAD signaling pathway. These findings indicate that iNKT activation and the resulting cell proliferation influence iron homeostasis.
\end{abstract}

Anaemia of chronic disease (ACD) or anaemia of inflammation is the second most prevalent cause of anaemia, after iron deficiency anaemia ${ }^{1}$. ACD is driven by the activation of immune cells and their production of inflammatory cytokines ${ }^{1}$. Hallmarks of ACD include disturbances in iron homeostasis that divert iron from the circulation into storage sites, thereby reducing iron availability for erythropoiesis ${ }^{2}$. Disrupted iron homeostasis in ACD is achieved via the regulation of genes involved in cellular iron uptake and export, and leads to increased uptake and retention of iron within cells of the reticuloendothelial system. Specifically, tumour necrosis factor alpha (TNF- $\alpha$ ), interleukin (IL)-1, IL-6, and interferon gamma (IFN- $\gamma$ ) are cytokines that can directly modulate the translation/transcription of genes involved in iron homeostasis, such as the iron-regulatory hormone hepcidin in the liver ${ }^{3}$. The main cell types that produce these cytokines include $\mathrm{T}$ lymphocytes and macrophages, and their activation contributes to $\mathrm{ACD}^{1,4}$.

The liver is the major regulator of systemic iron homeostasis through hepcidin production ${ }^{5,6}$ and is home to many immune cell types ${ }^{7}$, including conventional and non-conventional T cells ${ }^{8}$. In mice, invariant natural killer T (iNKT) cells are most abundant in the liver. These iNKT cells express T cell receptors (TCR) that recognize lipid or glycolipid antigens presented by the MHC class I-related glycoprotein CD1 $\mathrm{d}^{9,10}$. In the absence of effective lipid presentation by CD1d, iNKT cells accumulate in the liver and contribute to inflammation ${ }^{11}$. However, in the presence of obesity, presentation of endogenous lipids to iNKT cells in the liver also contributes

${ }^{1}$ Centre de Recherche du Centre Hospitalier de I'Université de Montréal (CRCHUM), Montréal, Québec, Canada. ${ }^{2}$ Département de Médecine, Université de Montréal, Montréal, Québec, Canada. ${ }^{3}$ Instituto de Medicina Molecular (iMM), Lisbon, Portugal. 'Département de Microbiologie, Infectiologie et Immunologie, Université de Montréal, Montréal, Québec, Canada. ${ }^{5}$ Maisonneuve-Rosemont Hospital Research Centre (CRHMR), Montréal, Québec, Canada. ${ }^{6}$ Nutrition and Microbiome Laboratory, CRCHUM-R10.426, 900 rue Saint-Denis, Montréal, Québec H2X 0A9, Canada. ${ }^{7}$ Present address: Centre INRS-Institut Armand-Frappier, Institut National de La Recherche Scientifique, 531 Boulevard des Prairies, Laval, Québec, Canada. ${ }^{\varpi}$ email: manuela.santos@ umontreal.ca 
A

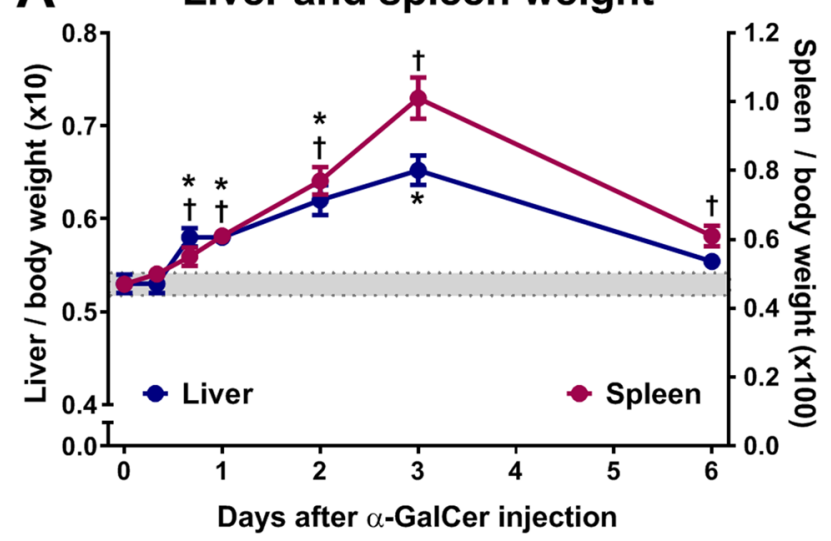

C

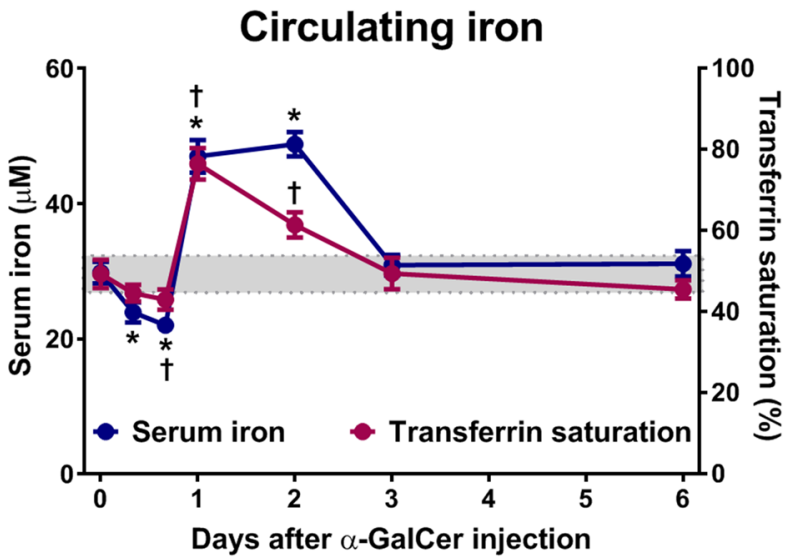

B Tissue iron

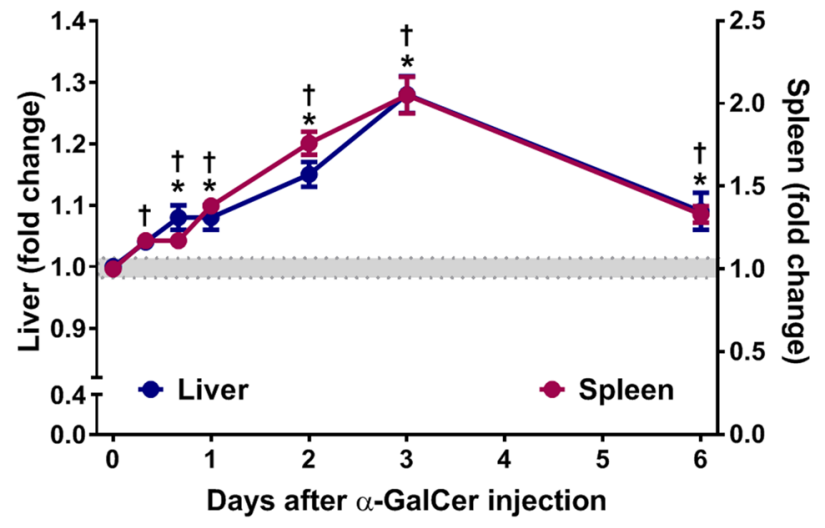

D Hepcidin and ferroportin 1 mRNA expression

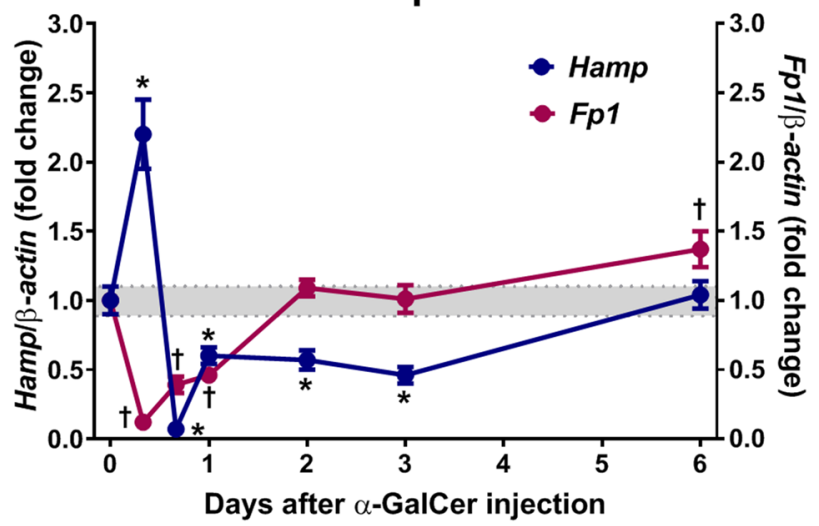

Figure 1. Time course of $\alpha$-GalCer-induced changes in systemic iron metabolism. Wild-type mice were injected with vehicle (indicated by the gray area across the graphs) or $100 \mu \mathrm{g} / \mathrm{Kg}$ body weight of $\alpha-\mathrm{GalCer}$. (A) Liver and spleen weights. (B) Total iron in liver and spleen. (C) Serum iron and transferrin saturation. (D) Hepcidin (Hamp) and ferroportin $1(F p 1)$ mRNA expression. Data are presented as mean \pm SEM for a minimum of $n=12$ mice per time point. Statistical analysis was performed with one-way ANOVA. ${ }^{\star}$ (blue lines) and ${ }^{\dagger}$ (purple lines) $P<0.01$, compared to mice injected with vehicle at each time point.

to inflammation ${ }^{12}$. Indeed, activated iNKT cells rapidly secrete both Th1- and Th2-type cytokines ${ }^{13}$, which facilitates the recruitment and activation of many other immune cells, such as NK cells, myeloid cells, and various T cell subsets, to stimulate anti-tumor immune responses ${ }^{14,15}$. As such, the release of large amounts of cytokines by activated iNKT cells ${ }^{13}$ may potentially affect iron homeostasis by inducing hepcidin expression in the liver ${ }^{16}$. Thus, iNKT cells represent a unique cell population that may influence iron metabolism.

Here, we investigated the influence of iNKT cell activation on iron metabolism. Our results indicate that iNKT cell activation induces profound alterations in iron homeostasis.

\section{Results}

Activation of iNKT cells in vivo with $\alpha$-GalCer induces changes in iron metabolism. The prototypical iNKT cell ligand, $\alpha$-galactosylceramide ( $\alpha$-GalCer), induces a potent primary iNKT cell response ${ }^{17}$. To evaluate the impact of acute iNKT cell activation on iron metabolism, we injected wild-type mice with $\alpha$-GalCer and monitored the mice for six days. As expected, $\alpha$-GalCer treatment led to a significant increase in liver and spleen weights, peaking at day 3 (Fig. 1A). This is in line with a robust iNKT cell activation, leading to immune cell recruitment and proliferation ${ }^{18,19}$. iNKT cell activation also impacted iron metabolism. Total iron levels in the liver and spleen increased, mirroring the increase in liver and spleen weights (Fig. 1B). In contrast, circulating iron levels, which were assessed by measuring serum iron levels and transferrin saturation, decreased during the first $6 \mathrm{~h}$ following a-GalCer treatment and was followed by a significant increase between 24 and $48 \mathrm{~h}$, with levels returning to normal by day 3 (Fig. 1C). In turn, hepcidin expression levels (Hamp) were elevated two-fold at $6 \mathrm{~h}$ after $\alpha$-GalCer treatment, and then suppressed from $12 \mathrm{~h}$ and up to day 3 (Fig. 1D). Ferroportin 1 (Fp1) levels were rapidly suppressed starting at $3 \mathrm{~h}$ and up to $48 \mathrm{~h}$ after treatment (Fig. 1D). Overall, these data show that activation of iNKT cells by $\alpha$-GalCer leads to biphasic changes in iron metabolism. 
Changes in iron metabolism induced by $\alpha$-GalCer depend on the presence of CD1d and iNKT cells. $a$-GalCer loaded onto CD1d specifically binds to and activates iNKT cells. Therefore, the changes in iron metabolism following in vivo $a$-GalCer treatment most likely resulted from iNKT cell activation. To determine if the changes in iron metabolism were a direct or indirect consequence of iNKT cell activation by a-GalCer presented by CD1d, we used CD1d-deficient mice $\left(C D 1 d^{--}\right)$, which lack both iNKT and type 2 NKT cells ${ }^{20}$. After $\alpha$-GalCer administration, $C D 1 d^{-/-}$mice had no variations in liver weight, and serum iron and hepcidin levels in the liver remained unaffected at $6 \mathrm{~h}$ and at $24 \mathrm{~h}$ (Fig. 2). These results demonstrate that $\alpha$-GalCer treatment induces changes in iron metabolism in a CD1d-dependent manner.

Next, to determine if the absence of changes in iron metabolism following a-GalCer treatment in $\mathrm{CD}_{1 d^{-/-}}$mice was either due to the absence of $\alpha$-GalCer presentation by CD1d or due to the absence of NKT cells, we assessed the effect of $\alpha$-GalCer on iron homeostasis using $J \alpha 18^{-/-}$mice. These mice are deficient for the Ja18 TCR segment and specifically lack Va14 iNKT cells, whereas all the other lymphoid cell lineages, including type 2 NKT cells, are intact ${ }^{21}$. The mice also express CD1d and are thus able to present $\alpha$-GalCer. When compared to wild-type mice, liver weights in $J \alpha 18^{-/-}$mice remained unchanged at $24 \mathrm{~h}$ post $\alpha$-GalCer-treatment (Fig. 3A). Moreover, serum iron (Fig. 3B) and hepcidin mRNA expression (Fig. 3C) remained unaltered at both $6 \mathrm{~h}$ and $24 \mathrm{~h}$ following $\alpha$-GalCer treatment. These results confirm that iNKT cells are indispensable for $\alpha$-GalCer-induced changes in iron homeostasis and demonstrate that iNKT cell activation is sufficient to trigger prominent changes in iron homeostasis.

The impact of $\alpha$-GalCer on iron homeostasis is independent of NK cells. We demonstrated that iNKT cell activation with $\alpha$-GalCer affects iron homeostasis. We then investigated other cellular downstream effectors that may contribute to the changes in iron homeostasis. Considering that changes in iron metabolism occurred within hours of $\alpha$-GalCer administration and that the changes did not persist beyond three days (Fig. 1), we examined the cellular components of innate immunity, such as NK cells, known to respond within this timeframe ${ }^{15,22}$. We depleted NK cells using the anti-asialoGM1 ( $a$-AGM1) antibody ${ }^{23}$, which resulted in more than 75\% depletion of NK cells in the liver (Supplementary Fig. 1). Two groups of mice, control isotype Ig-injected and $\alpha$-AGM1 antibody-treated, were injected with $\alpha$-GalCer or vehicle $24 \mathrm{~h}$ after NK cell depletion. As shown in Fig. 4, NK cell-depleted mice had similar responses to a-GalCer administration as control mice, showing an increase in liver weight at $24 \mathrm{~h}$ (Fig. 4A) as well as the biphasic changes in serum iron (Fig. 4B) and hepcidin mRNA expression (Fig. 4C). Indeed, while serum iron levels in both control and NK cell-depleted mice were reduced at $6 \mathrm{~h}$ and increased at $24 \mathrm{~h}$, the hepcidin mRNA levels were conversely increased at $6 \mathrm{~h}$ and decreased at $24 \mathrm{~h}$ after $\alpha-G a l C e r$ treatment. Taken together, these results indicate that NK cells are not required for $\alpha$-GalCer-induced disturbances in iron metabolism.

Role of Kupffer cells in $\alpha$-GalCer-induced changes in iron metabolism. In addition to NK cells, Kupffer cells, the resident macrophages of the liver, are another likely cellular candidate that may contribute to $\alpha$-GalCer-induced changes in iron metabolism as they produce vast amounts of IL- $6^{24}$. Since IL- 6 plays a major role in hepcidin regulation during inflammation ${ }^{25}$, we depleted Kupffer cells by pre-treating mice with clodronate liposome (c-lip) and assessed the depletion efficiency by RT-PCR using primers for Kupffer cell markers, F4/80 and Clec4f. When compared to control mice treated with phosphate-buffered saline-liposomes (PBS-lip), both F4/80 and Clec4f mRNA expression were significantly reduced in c-lip-treated mice, demonstrating that c-lip induced an efficient deletion of Kupffer cells in the liver (Supplementary Fig. 2). Importantly, the proportion and activation state of iNKT cells, as quantified by CD69 expression, was not influenced by c-lip treatment (Supplementary Fig. 3). PBS-lip-treated and c-lip-treated mice were subsequently challenged with $a$-GalCer treatment. Interestingly, the liver weights in both treatment groups were comparable and increased at $24 \mathrm{~h}$ posta-GalCer treatment (Fig. 5A). This result suggests that depletion of Kupffer cells is not sufficient to prevent liver enlargement driven by iNKT cell activation.

We further examined the impact of Kupffer cell depletion on iron metabolism. When compared to PBS-liptreated mice, $c$-lip-treatment alone (without $\alpha$-GalCer treatment) resulted in significantly lower serum iron levels at $6 \mathrm{~h}$ but not at $24 \mathrm{~h}$ (Fig. 5B, comparison of vehicle treatment in PBS-lip and c-lip groups). This suggests that depletion of Kupffer cells per se has a transient impact on serum iron levels. Regardless, at $6 \mathrm{~h}$ following a-GalCer administration, serum iron levels decreased to a similar extent in both PBS-lip and c-lip treated mice (Fig. 5B), suggesting that Kupffer cells do not significantly contribute to the early phase of iron homeostasis disruption. At $24 \mathrm{~h}$ after $\alpha$-GalCer-treatment, serum iron levels returned to normal levels in Kupffer cell-depleted mice injected with vehicle. However, $\alpha$-GalCer treatment did not further elevate serum iron levels in Kupffer cell-depleted (c-lip-treated) mice relative to PBS-lip-treated mice. Altogether, these results suggest that Kupffer cells contribute to the maintenance of serum iron levels in the absence of acute stimulation and to the increase in serum iron levels following iNKT cell activation.

The acute hypoferremic response is accompanied by a strong induction of hepatic hepcidin mRNA expression ${ }^{25}$. Accordingly, at $6 \mathrm{~h}$ after vehicle administration, hepcidin mRNA levels were increased in c-liptreated mice relative to PBS-lip treated mice, further supporting an impact of Kupffer cell deletion on iron metabolism in the absence of inflammatory challenge (i.e., without $\alpha$-GalCer treatment, Fig. $5 \mathrm{C}$ ). At $6 \mathrm{~h}$ post- $\alpha$-GalCer treatment hepcidin mRNA levels were similarly increased in both PBS-lip- and c-lip-treated mice (Fig. 5C). Therefore, Kupffer cells do not contribute significantly to early changes in iron metabolism after $\alpha$-GalCer treatment. In addition, hepcidin mRNA levels were similarly decreased at $24 \mathrm{~h}$ post- $\alpha$-GalCer administration in both PBS-lip- and c-lip-treated mice (Fig. 5C). These results indicate that Kupffer cells are not essential for regulating hepcidin expression in response to $\alpha$-GalCer treatment but contribute to hepcidin regulation under steady-state conditions. 


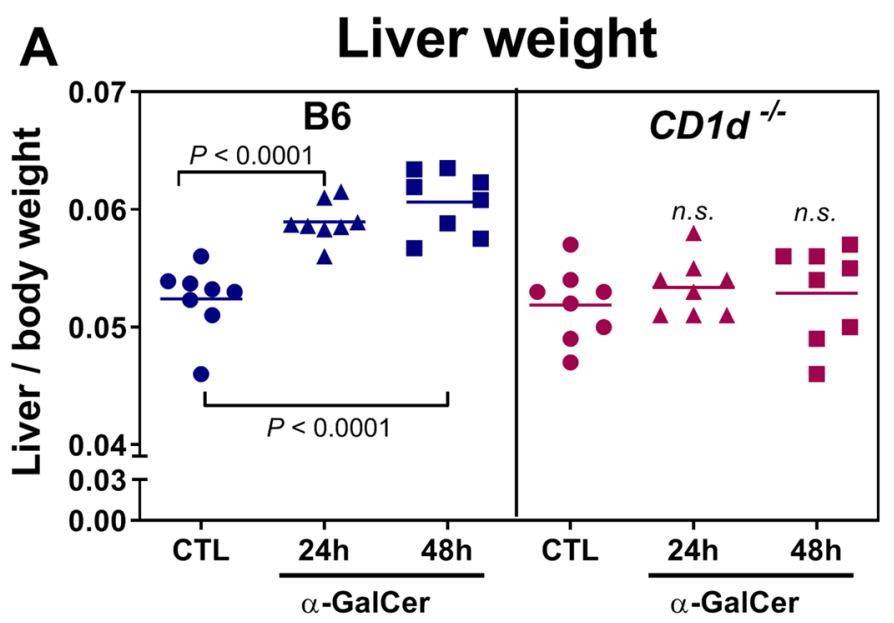

B Serum iron

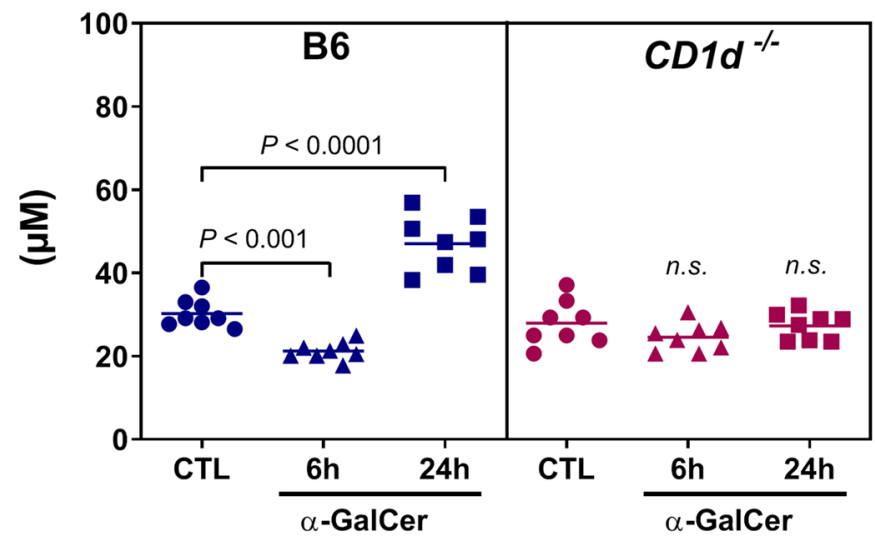

C Hepcidin mRNA expression

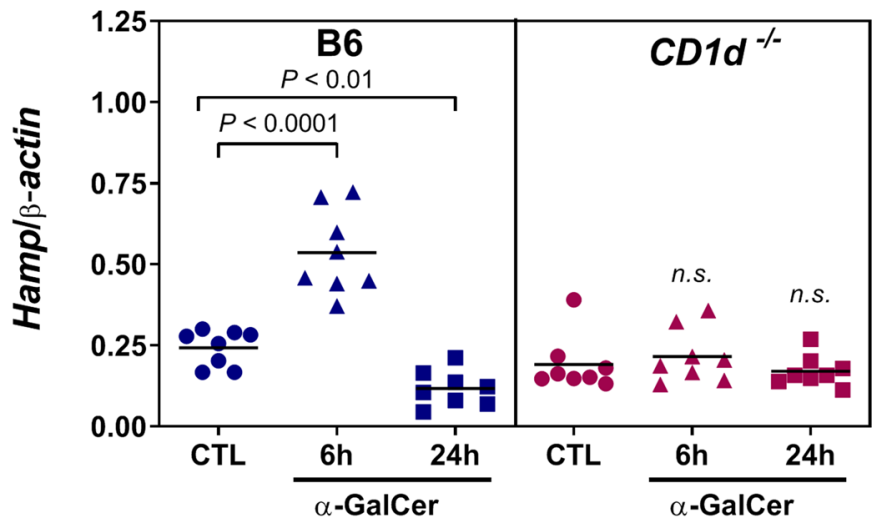

Figure 2. Iron metabolism changes induced by a-GalCer-mediated iNKT activation are abolished in $C D 1 d^{-1-}$ mice. Wild-type and CD1 $d^{-1-}$ mice were injected with vehicle (CTL) or $100 \mu \mathrm{g} / \mathrm{Kg}$ body weight of $\alpha$-GalCer. (A) Liver weight. (B) Serum iron. (C) Hepcidin mRNA expression. Each symbol represents one mouse with the bar indicating the mean; $n=8$ per group. Statistical analysis was performed with one-way ANOVA. n.s., not significant compared to control mice (CTL) injected with vehicle.

Liver damage after $\alpha$-GalCer-mediated iNKT activation. Our results so far indicate that biphasic changes in iron homeostasis induced by $\alpha-G a l C e r$ are mediated by iNKT cells. The iNKT cell-driven impact on iron homeostasis does not involve the activation of NK cells, whereas Kupffer cells contribute to the regulation 


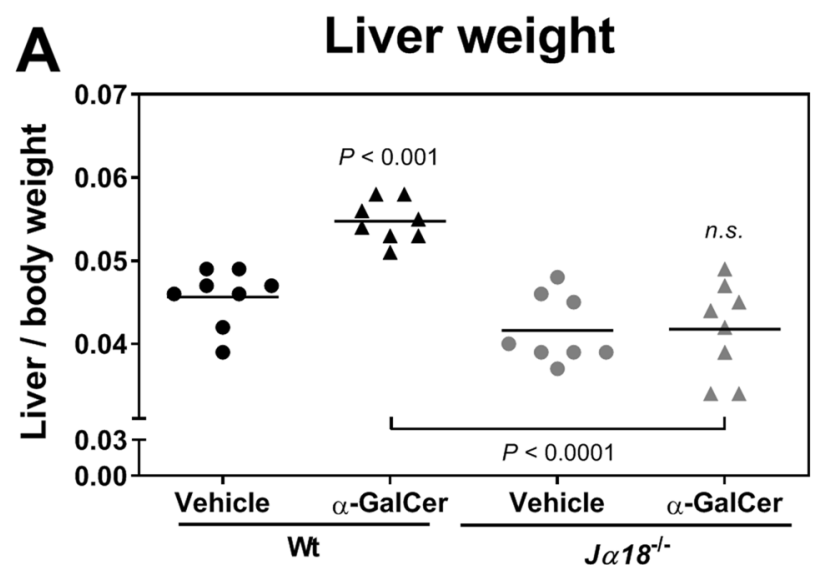

B Serum iron - $6 \mathrm{~h}$

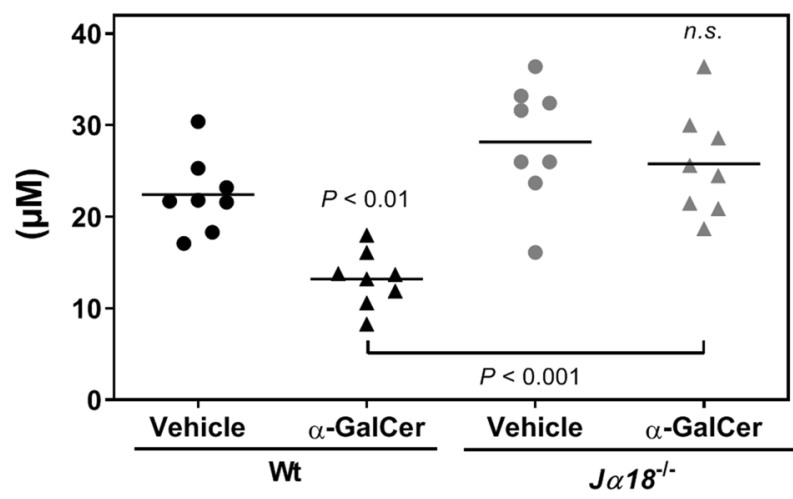

C Hepcidin mRNA - $6 \mathrm{~h}$

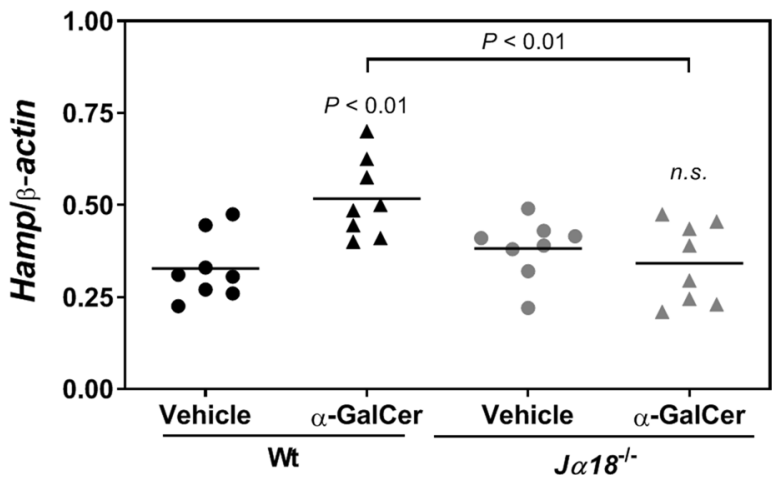

Serum iron - 24h

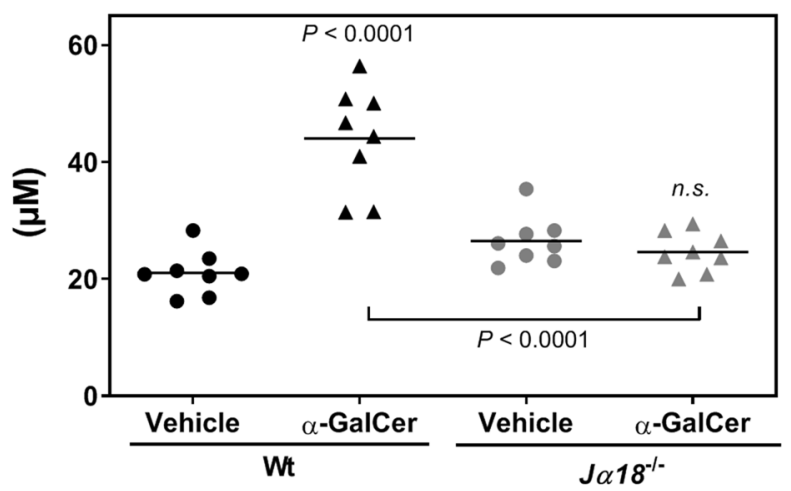

Hepcidin mRNA - 24h

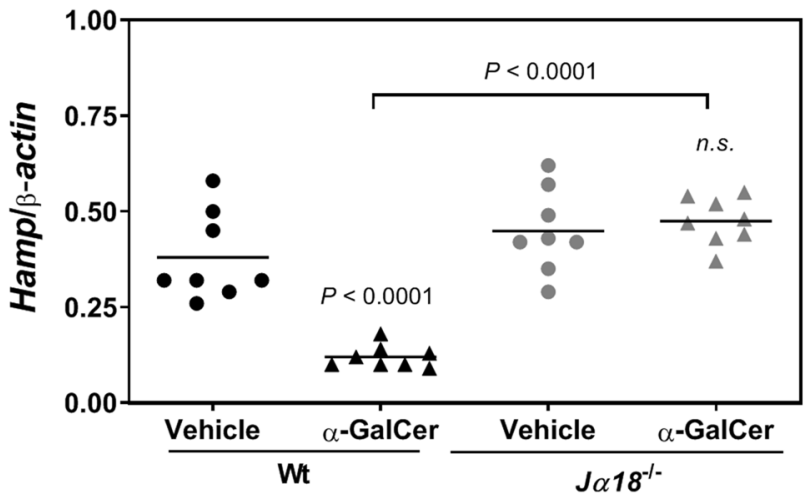

Figure 3. $J \alpha 18^{-/-}$mice lacking V 14 iNKT cells fail to respond to $\alpha$-GalCer treatment and show no change in iron metabolism. Wild-type (Wt) and $J \alpha 18^{-/-}$mice were injected with vehicle or $100 \mu \mathrm{g} / \mathrm{kg}$ body weight of a-GalCer. (A) Liver weight $24 \mathrm{~h}$ post-treatment. (B) Serum iron at $6 \mathrm{~h}$ and $24 \mathrm{~h}$ post-treatment. (C) Hepcidin mRNA expression at $6 \mathrm{~h}$ and $24 \mathrm{~h}$ post-treatment. Each symbol represents one mouse with the bar indicating the mean; $n=8$ per group. Statistical analysis was performed with one-way ANOVA. $n$.s. not significant compared to control mice injected with vehicle.

of serum iron levels and hepcidin expression in the absence of iNKT stimulation. In addition to inflammatory cytokine production, iNKT cells activated with $\alpha$-GalCer can induce liver damage ${ }^{26}$, which could explain partially the increase in circulating and tissue iron levels. To quantify liver damage, we measured serum alanine aminotransferase (ALT) levels, which were elevated up to $24 \mathrm{~h}$ post-treatment with $\alpha$-GalCer (Fig. 6A). 


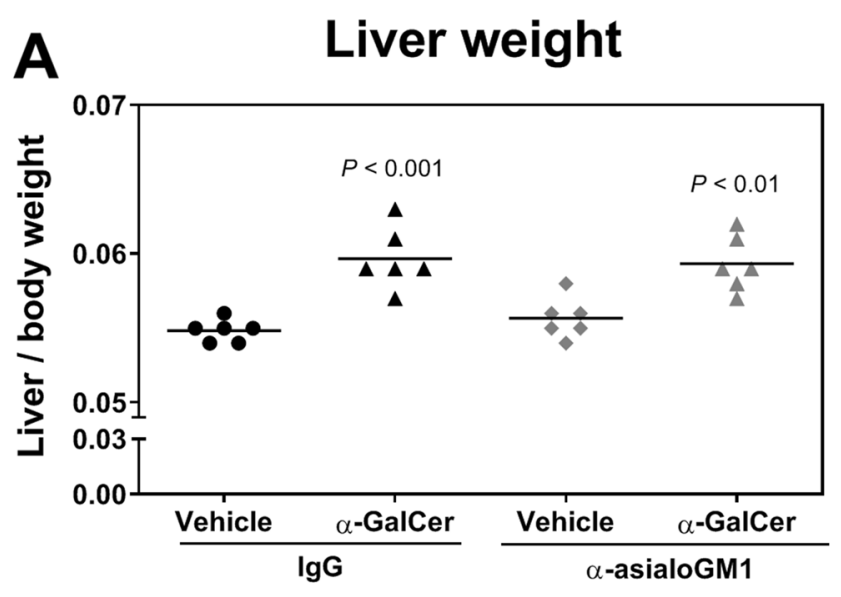

B Serum iron - $6 h$

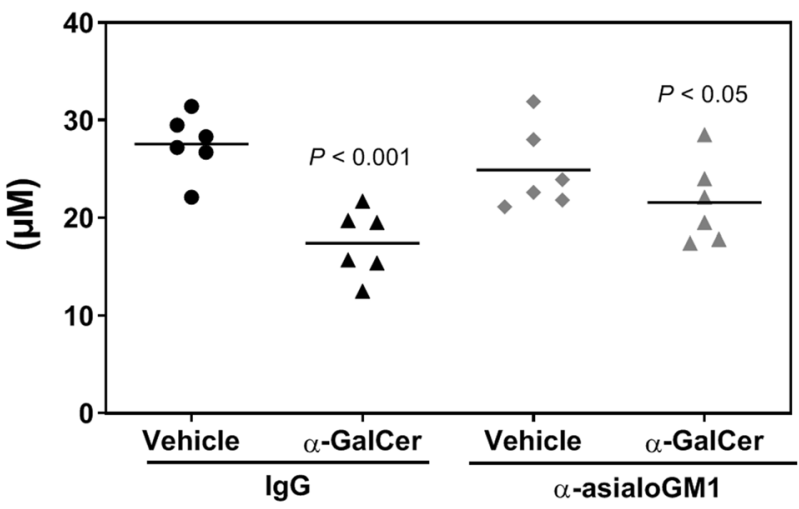

C Hepcidin mRNA - 6h

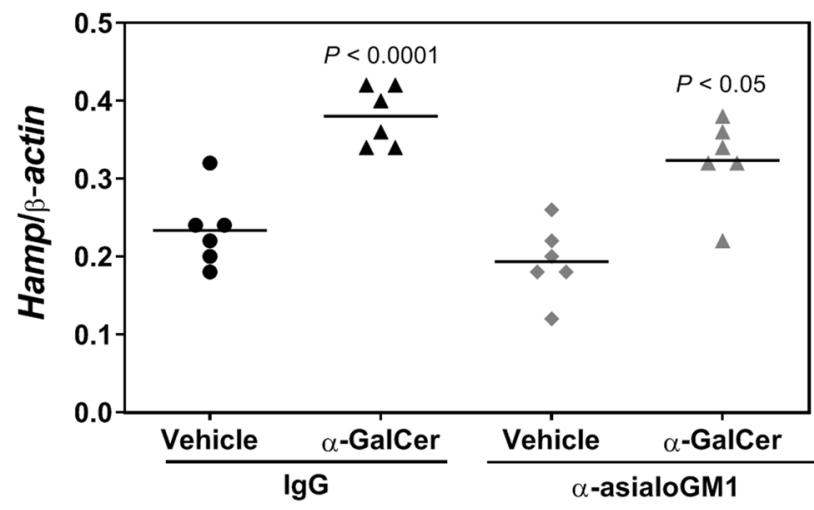

Serum iron - $24 \mathrm{~h}$

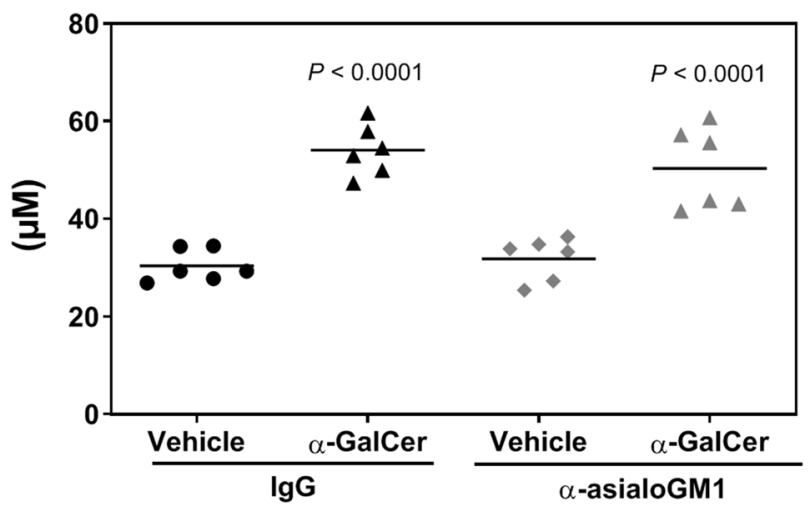

Hepcidin mRNA - 24h

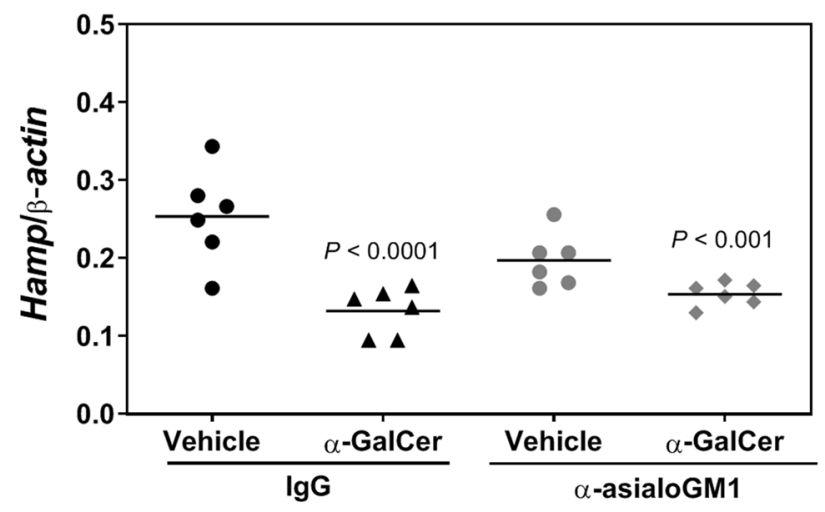

Figure 4. Iron metabolism changes induced by a-GalCer-mediated iNKT activation is independent of NK cells. Mice were injected with control isotype Ig (IgG) or with $\alpha$-asialoGM1 antibodies before the administration of vehicle or $100 \mu \mathrm{g} / \mathrm{Kg}$ body weight of $\alpha$-GalCer. (A) Liver weight $24 \mathrm{~h}$ post-treatment. (B) Serum iron at $6 \mathrm{~h}$ and $24 \mathrm{~h}$ post- $\alpha-$ GalCer treatment. (C) Hepcidin mRNA expression at $6 \mathrm{~h}$ and $24 \mathrm{~h}$ post- $\alpha$-GalCer treatment. Each symbol represents one mouse with the bar indicating the mean; $n=6$ per group. Statistical analysis was performed with one-way ANOVA.

Regulation of BMPISMAD and STAT3 pathways after $\alpha$-GalCer-mediated iNKT activation. Regulation of hepcidin expression by iron involves signaling through the bone morphogenetic protein (BMP) and Sma- and Mad-related protein 4 (BMP/SMAD4) pathway that regulates hepcidin via the SMAD1, SMAD5, and SMAD8 proteins ${ }^{27}$. This iron-signaling pathway involves upregulation of BMPs, particularly $\mathrm{BMP}^{28}$, in response to heightened iron levels ${ }^{29,30}$. Hence, we next measured the levels of Bmp6 mRNA expression levels in response to $a$-GalCer acute treatment. Despite the rise in serum and tissue iron, $B m p 6$ mRNA levels substantially decreased as early as $6 \mathrm{~h}$ post- $\alpha$-GalCer treatment (Fig. 6B). 


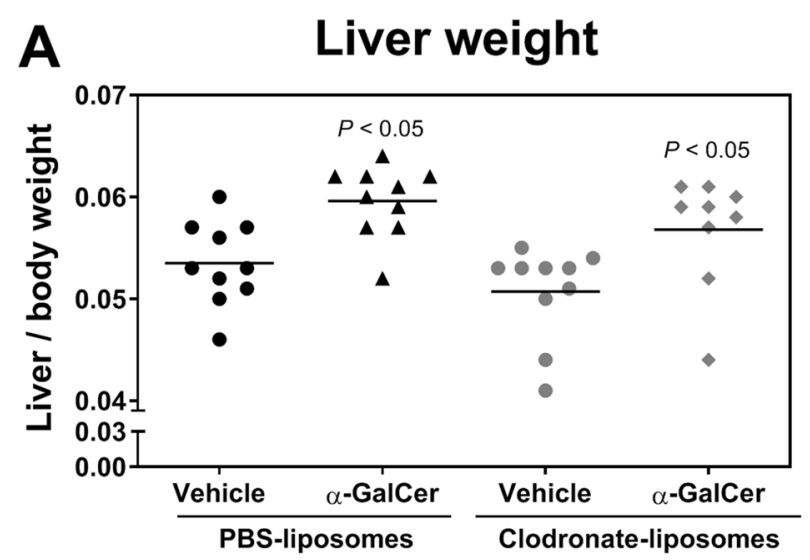

\section{B Serum iron - $6 \mathrm{~h}$}

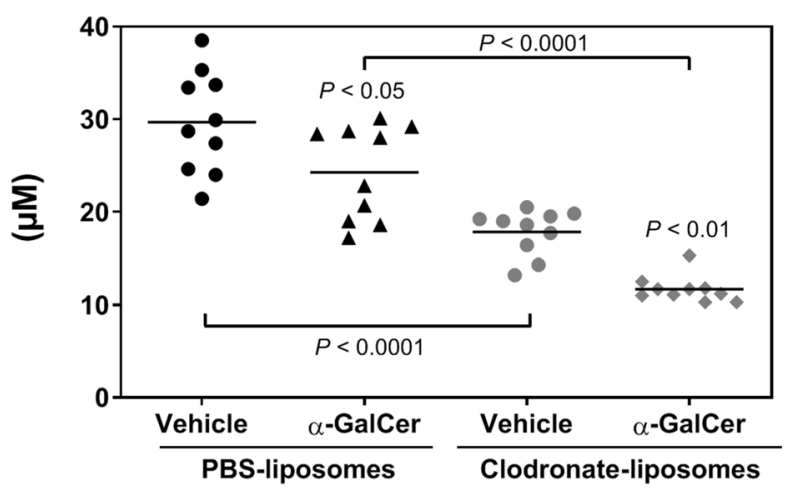

C Hepcidin mRNA - $6 \mathrm{~h}$

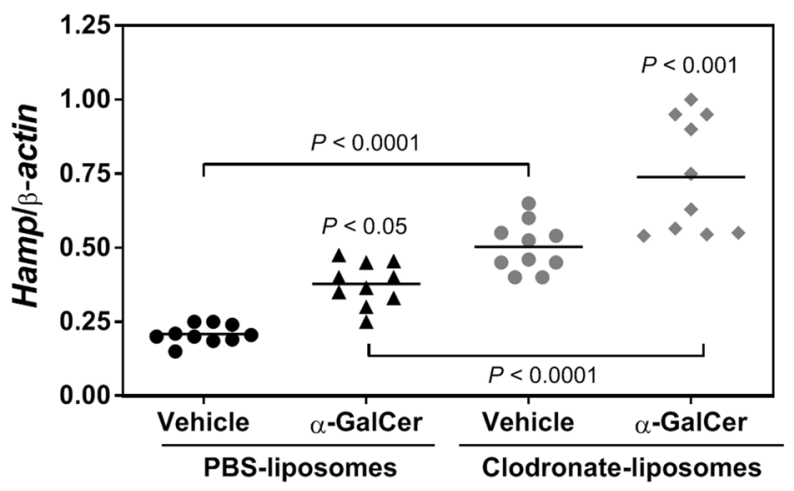

Serum iron - 24h

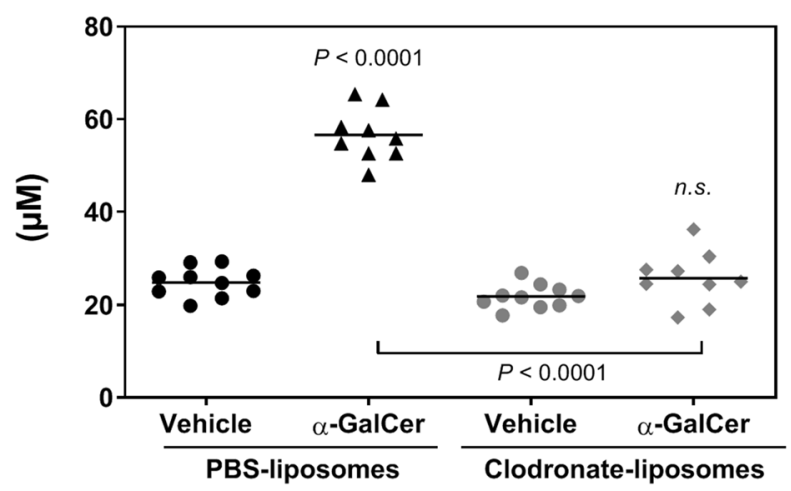

Hepcidin mRNA - 24h

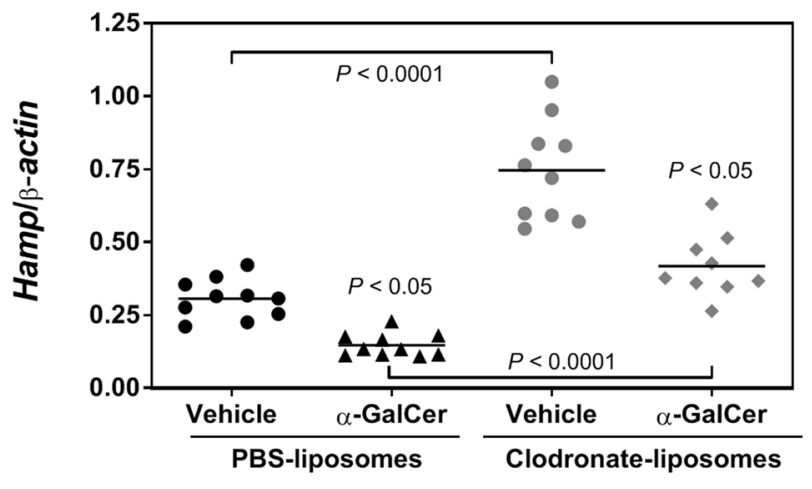

Figure 5. Influence of Kupffer cells on the iron metabolism changes induced by a-GalCer-mediated iNKT activation. Mice were injected with PBS-liposomes or with clodronate-liposomes $48 \mathrm{~h}$ before the administration of vehicle or $100 \mu \mathrm{g} / \mathrm{Kg}$ body weight of $\alpha$-GalCer. (A) Liver weight $24 \mathrm{~h}$ post-treatment. (B) Serum iron at $6 \mathrm{~h}$ and $24 \mathrm{~h}$ post- $\alpha$-GalCer treatment. (C) Hepcidin mRNA expression at $6 \mathrm{~h}$ and $24 \mathrm{~h}$ post- $\alpha$-GalCer treatment. Each symbol represents one mouse with the bar indicating the mean; $n=9-10$ per group. Statistical analysis was performed with one-way ANOVA. n.s. not significant compared to control mice injected with vehicle.

Once the BMP6/SMAD pathway is activated by iron, inhibitory SMADs, particularly SMAD7, are also upregulated $^{31}$. However, Smad7 mRNA levels were significantly suppressed after $\alpha$-GalCer administration (Fig. 6B). This indicates that the lack of response to elevated iron levels was not due to an exaggerated expression of SMAD7, but that instead, Smad7 expression levels appeared to follow a general pattern of inhibition of $\mathrm{BMP} / \mathrm{SMAD}$ signaling in response to $\alpha-\mathrm{GalCer}$.

To further confirm that hepcidin suppression in response to $\alpha$-GalCer treatment was due to inhibition of the BMP/SMAD pathway, we assessed phosphorylation levels of SMAD1/5/8 in liver nuclear extracts. We found 
A

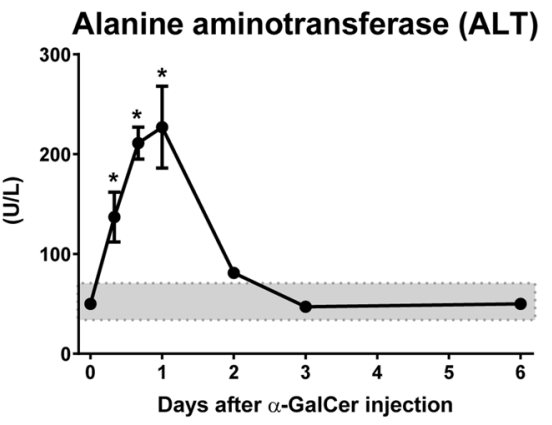

B Bmp6 and Smad7 mRNA expression

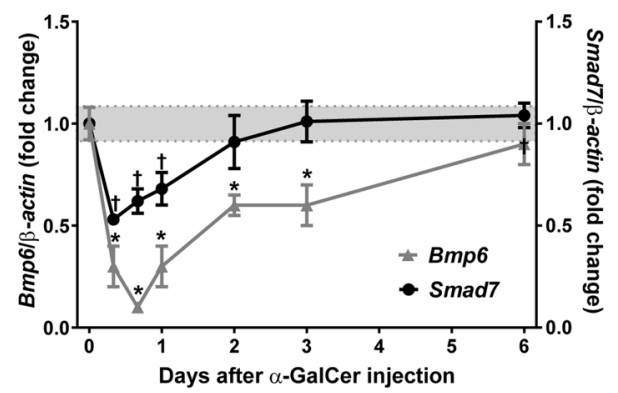

C

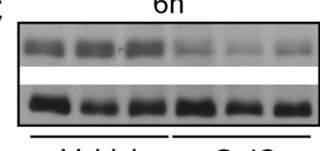

Vehicle $\alpha$-GalCer

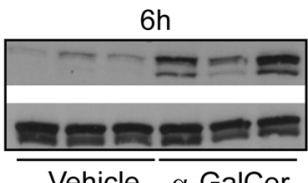

Vehicle $\alpha$-GalCer

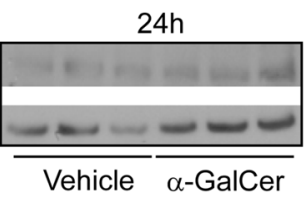

$24 \mathrm{~h}$

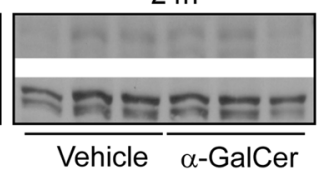

pSMAD $1 / 5 / 8$

Total SMAD1/5/8

pSTAT3

Total STAT3

Figure 6. Liver damage induced by $a-G a l C e r$ and inhibition of BMP/SMAD signaling pathway. Wild-type mice were injected with vehicle (indicated by the gray area across the graphs) or $100 \mu \mathrm{g} / \mathrm{Kg}$ body weight of $\alpha$-GalCer. (A) Liver alanine aminotransferase levels. (B) Bmp6 and Smad7 mRNA expression in the liver. (C) Liver nuclear extracts analyzed by western blotting. Upper blots: phosphorylated SMAD1/5/8 (pSMAD1/5/8) and total SMAD1/5/8; Lower blots: phosphorylated STAT3 (pSTAT3) and total STAT3. The full-length blots are presented in Supplementary Fig. 6. Data in (A) and (B) are presented as mean \pm SEM for a minimum of $n=12$ mice per time point. Statistical analysis was performed with one-way ANOVA. ${ }^{\star, \dagger} P<0.01$, compared to mice injected with vehicle at each time point.

that SMAD1/5/8 phosphorylation was decreased at $6 \mathrm{~h}$ and $24 \mathrm{~h}$ post- $\alpha$-GalCer treatment (Fig. $6 \mathrm{C}$ ), confirming that the BMP/SMAD pathway was not activated in response to elevations in circulating and tissue iron induced by $\alpha$-GalCer.

Hepcidin levels are additionally regulated by inflammatory cytokines, such as IL-6, via the signal transducer and activator of transcription 3 (STAT3) pathway ${ }^{32}$. Accordingly, we found that at $6 \mathrm{~h}$ but not at $24 \mathrm{~h}$ posttreatment, STAT3 phosphorylation was enhanced, which was consistent with hepcidin induction during the early phase (Fig. 6C). Overall, these data indicate that at earlier stages after iNKT activation, STAT3 signaling is enhanced while BMP/SMAD signaling is suppressed. The outcome of these opposing signals of Hamp induction via STAT3 phosphorylation vs. Hamp inhibition via BMP/SMAD suppression, is the activation of Hamp expression via the inflammatory, STAT3-mediated pathway. In contrast, inhibition of the BMP/SMAD signaling pathway predominates at the stage when STAT3 activation ceases, and consequently Hamp expression is repressed.

$\alpha$-GalCer treatment induces immune cell proliferation in the liver and spleen. To further understand the increase in total liver iron induced by $a$-GalCer treatment (Fig. 1B), we measured circulating and liver ferritin levels. Serum ferritin levels increased at $6 \mathrm{~h}$, followed by a significant decrease starting at $48 \mathrm{~h}$ to day 3 , while liver ferritin levels followed a similar kinetic by increasing with a slight delay at $24 \mathrm{~h}$ and significantly decreasing at $72 \mathrm{~h}$ (Fig. 7A). Ferric iron staining of liver samples by DAB-enhanced Perl's Prussian blue showed a 
A

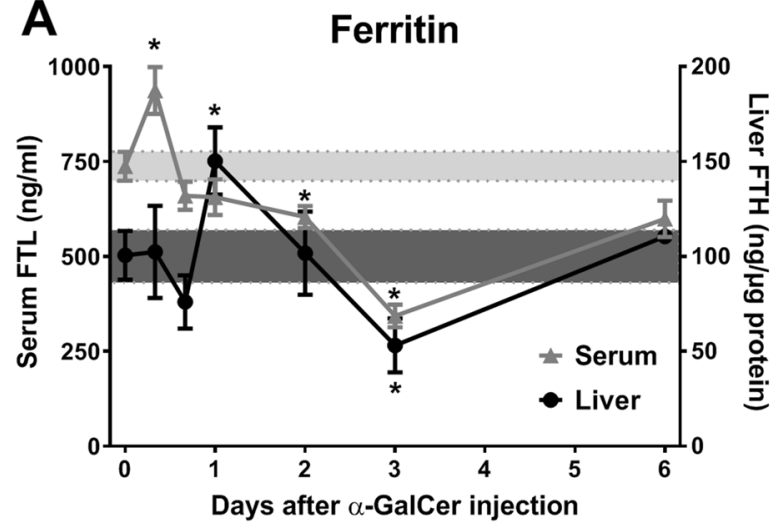

C Liver proliferating cells

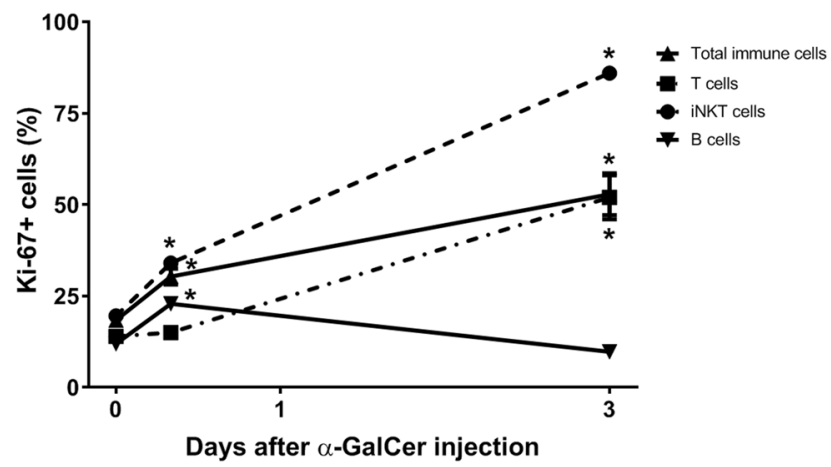

B Transferrin Receptor

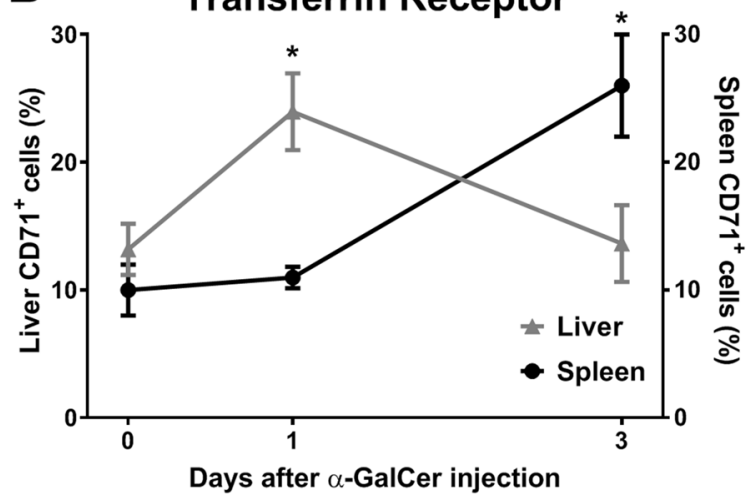

D Spleen proliferating cells

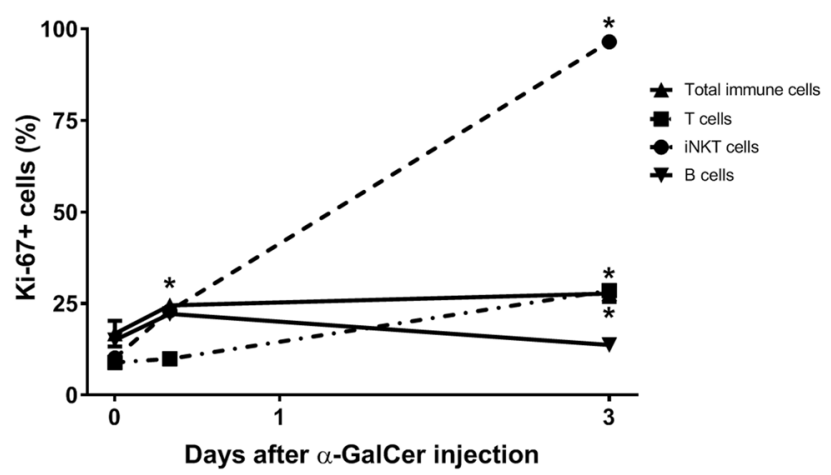

Figure 7. Serum and liver ferritin changes and immune cell proliferation induced by a-GalCer. Wild-type mice were injected with vehicle or $100 \mu \mathrm{g} / \mathrm{Kg}$ body weight of $\mathrm{a}$-GalCer. (A) Serum and liver ferritin levels. (B) Transferrin receptor (CD71) expression within mononuclear cells isolated from liver and spleen. (C) Proliferating cells in the liver. (D) Proliferating cells in the spleen. Data are presented as mean \pm SEM for a minimum of $n=3-6$ mice per time point. Statistical analysis was performed with one-way ANOVA. ${ }^{\star} P<0.05$, compared to mice injected with vehicle.

similar distribution pattern (Supplementary Fig. 4). These results indicate that the extra iron in the liver was not being stored in ferritin or hemosiderin. Since iron is required for DNA synthesis in proliferating cells ${ }^{33}$, where it would not be stored in ferritin, we directly assessed the levels of CD71 or transferrin receptor (TfR) on mononuclear cells isolated from the liver and spleen using flow cytometry. The percentage of cells expressing CD71 was significantly elevated at $24 \mathrm{~h}$ in the liver and at $72 \mathrm{~h}$ in the spleen (Fig. 7B). These data suggest that immune cells were increasing their ability to uptake iron for proliferation rather than for storage into ferritin.

$a$-GalCer treatment induces activation and proliferation of iNKT cells $s^{14,15}$. These activated iNKT cells produce cytokines, which lead to the recruitment, activation and proliferation of other immune cells ${ }^{16,17}$. Indeed, we found that at day 3 , the proportion and absolute number of iNKT cells was significantly increased in the liver of $\alpha$-GalCer-treated mice relative to controls (Supplementary Fig. 5). In line with this increase in number, we found that iNKT cells were actively proliferating, as quantified by the expression of Ki-67 (Fig. 7C,D). The activation of iNKT cells also resulted in the proliferation of other immune cells. Using CD45 to identify all immune cells, we noted an increase in the Ki-67 proliferation marker as early as $6 \mathrm{~h}$ following $\alpha$-GalCer administration (Fig. 7C,D). Whereas B cell proliferation was modestly increased, T cell proliferation was significantly induced in both the liver and the spleen (Fig. 7C,D). Overall, $a$-GalCer-mediated activation of iNKT cells induced substantial immune cell proliferation in both the liver and spleen. Notably, the proliferation was more prominent in the liver, where iNKT cells are most abundant.

\section{Discussion}

The aim of this study was to investigate the influence of activated iNKT cells on iron homeostasis. Our work suggests that iNKT activation has particular effects in iron homeostasis that could be relevant for treatments aimed at regulating hepcidin expression. A possible role for iNKT cells in modifying iron metabolism is suggested by their ability to secrete cytokines upon activation, and by their predominant location in mouse liver, where the major regulator of iron homeostasis, hepcidin, is produced. Hepcidin regulates systemic iron homeostasis via the hepcidin/ferroportin axis, as it binds to ferroportin 1 and induces ferroportin internalization and degradation ${ }^{34}$. Decreased ferroportin levels result in lowering intestinal iron absorption and iron export from macrophages and Kupffer cells, which are responsible for iron recycling. Therefore, hepcidin levels are tightly regulated by 
inflammation, anaemia, hypoxia, and iron levels ${ }^{35}$, and the mechanisms that are involved overlap to control immune responses, prevent iron toxicity, and respond to changes in erythropoietic demand ${ }^{36}$. Here, we show that $\alpha$-GalCer-mediated iNKT cells activation in vivo results in biphasic changes in systemic iron homeostasis.

The changes in iron metabolism triggered by $\alpha$-GalCer were abolished in CD1 $d^{-1-}$ mice. Since $\alpha-G a l C e r$ is a highly specific ligand for CD1d, this rules out possible unspecific effects, including those unrelated to antigen presentation. This also highlights a specific role for iNKT cells, confirmed by the lack of response in $J \alpha 18^{-/-}$mice. Indeed, while $C D 1 d^{-1-}$ mice lack all NKT cell subsets, $J \alpha 18^{-1-}$ mice are specifically devoid of Va14 iNKT cells ${ }^{21}$. Interestingly, iron in turn may influence iNKT levels, as shown in patients with hereditary hemochromatosis, an iron overloading disease. These individuals show a decrease in iNKT cells that is more pronounced in patients with higher iron levels ${ }^{37}$. Finally, using anti-asialoGM1 antibodies, we ruled out a role for NK cells, which undergo proliferation and activation after $\alpha$-GalCer administration.

Kupffer cells, the resident macrophages of the liver, have been historically studied in regard to iron metabolism as they are major producers of pro-inflammatory cytokines. In addition, Kupffer cells and macrophages play a fundamental role in iron recycling after erythrophagocytosis ${ }^{38}$. In our study, c-lip depletion of Kupffer cells alone significantly altered iron homeostasis, as shown by a decrease in serum iron accompanied by increased hepcidin expression. Similar effects after Kupffer cell depletion have been previously reported ${ }^{39}$. We demonstrate that these changes are not due to secondary activation of iNKT cells following Kupffer cell depletion. In addition, our depletion experiments demonstrated that Kupffer cells are dispensable for $\alpha$-GalCer-induced modulation of hepcidin. Our findings support and add to previous work by others, which demonstrated that Kupffer cells do not play a role in regulating hepcidin expression in response to inflammation ${ }^{39,40}$ and iron ${ }^{39-41}$.

We followed iron-related parameters after a single injection of $\alpha$-GalCer to activate iNKT cells in C57BL/6 wild-type mice. Upon injection of $\alpha$-GalCer, an early response was observed with decreases in serum iron, transferrin saturation, and FP1 expression, while hepcidin expression increased. These early responses are similar to the changes observed upon lipopolysaccharide injection, which are attributed to inflammatory cytokines ${ }^{32,42}$ and are consistent with the well-documented ability of activated NKT cells to rapidly release copious amounts of the proinflammatory cytokines IFN- $\gamma$, TNF- $\alpha$, and IL- 6 in circulation and in the liver ${ }^{43,44}$. Accordingly, we observed an increase in STAT3 phosphorylation at $6 \mathrm{~h}$ post-treatment. This may explain the parallel induction of hepcidin at this early phase, as STAT3 activation has been shown to induce hepatic hepcidin expression in response to inflammation ${ }^{32}$. Interestingly, at the same $6 \mathrm{~h}$ time point, SMAD1/5/8 phosphorylation was downregulated, which would downregulate hepcidin expression towards hepcidin suppression. This agrees with previous work showing that the level of hepcidin expression levels in the presence of opposing signaling is determined by the strength of the individual stimuli which, in our study, is the upregulation of STAT3 phosphorylation ${ }^{36}$.

A second phase following a-GalCer treatment involved a rise in tissue and serum iron levels but, paradoxically, hepcidin levels were strongly inhibited. The increase in circulating and tissue iron levels may be partially due to liver damage, since administration of $\alpha$-GalCer to mice has been shown to induce immune-mediated liver injury and cell death ${ }^{26}$ that may be accompanied by iron release from dying cells. Our results corroborate these earlier studies, based on our observation of elevated serum ALT levels that peaked between 12 and $24 \mathrm{~h}$ post-treatment. Alternatively, or concomitantly, Kupffer cell may also be involved in the increase in serum iron levels, since their depletion seemed to abolish the serum iron surge at $24 \mathrm{~h}$.

The rise in iron levels would be expected to modulate hepcidin levels by inducing its expression, as found in mice treated with iron-enriched diets ${ }^{6,45,46}$ or injected with iron-dextran ${ }^{6}$. At $24 \mathrm{~h}$ after acute $\alpha$-GalCer treatment, STAT3 phosphorylation returned to normal. Hence, non-inflammatory pathways regulate hepcidin expression at the later stage/second phase. The iron-sensing pathway initiates a sequence that starts with an increase in BMP levels, notably BMP6 ${ }^{30,47}$, binding to BMP receptors, followed by activation of SMAD1/5/8/phosphorylation ${ }^{47}$ and binding to SMAD $4^{48}$. The resulting SMAD complex translocates into the nucleus and binds to the BMP responsive element in the Hamp promoter region ${ }^{49}$.

Previous studies demonstrated that both circulating and tissue iron activate the BMP/SMAD signaling pathway to modulate hepcidin expression, albeit targeting different levels of the pathway ${ }^{29}$. While elevation of liver iron levels induces hepatic expression of Bmp6 in the liver, increased transferrin saturation activates SMAD1/5/8 phosphorylation downstream of BMP6. Intriguingly, in mice treated with a-GalCer, liver Bmp6 levels were strongly suppressed, and SMAD1/5/8/phosphorylation did not increase despite elevated levels of circulating iron. This suggests that the inhibition of hepcidin mRNA expression is related to a lack of activation of the BMP6/ SMAD pathway in response to elevated circulating iron. In our setting, Smad7 expression was also significantly suppressed, ruling out a possible activation of inhibitory SMAD7, which functions as a feedback inhibitor of the BMP/SMAD pathway ${ }^{31}$. In addition, inhibitory SMAD7 was previously shown to follow the overall activation of the SMAD1/5/8 signaling pathway and thus, was significantly modulated by both acute and chronic iron administration $^{29}$. Therefore, downregulation of $S m a d 7$ expression in our studies further supports the view that a-GalCer suppressed hepcidin expression via inhibition of the BMP6/SMAD pathway.

A decrease of hepatic Bmp6 mRNA levels in the presence of heightened liver iron has also been described in conditional knockout models of the iron exporter ferroportin ${ }^{50}$. These mouse models showed decreased $B m p 6$ expression and phosphorylated SMAD1/5/8 as well as decreased expression of Hamp in the liver, despite elevated liver iron loads. The investigators attributed the decrease in Bmp6 mRNA to a liver-independent signal generated in response to high iron demand for erythropoiesis. In our study, we show that $\alpha$-GalCer strongly stimulates the proliferation of immune cells, including NKT, B and T lymphocytes, as shown by others ${ }^{18,19,26}$. Moreover, lymphocytes are known to increase the synthesis and expression of surface TfR in response to the increased iron demand during proliferation ${ }^{51}$. Accordingly, we also show a significant increase in cells expressing TfR, consistent with the need to increase transferrin uptake to provide iron for fundamental cellular processes, especially for DNA synthesis $^{33}$. Heightened iron demand to support immune cell proliferation in response to $a$-GalCer may partially explain the inhibition of the BMP/SMAD pathway and, consequently, the downregulation of Hamp expression. 
In summary, the present work describes the effects of $\alpha$-GalCer on iron homeostasis and demonstrates that iNKT cells are essential for $\alpha$-GalCer effects. Activation of iNKT cells in vivo triggers substantial immune cell proliferation that translated into increased iron demand, contributing to a disassociation between temporary rises in circulating and tissue iron, and a marked suppression of hepcidin expression in the liver via inhibition of the $\mathrm{BMP} / \mathrm{SMAD}$ pathway. Altogether, our findings suggest that the iNKT/CD1d system plays an important role in iron homeostasis and that modulation of the iNKT/CD1d pathway may be useful to regulate hepcidin expression.

\section{Methods}

Mice. This study was carried out in accordance with Canadian Council on Animal Care guidelines. The protocol was evaluated and approved by the institutional Animal Care Committee of the CRCHUM ("Supplementary methods"). C57BL/6 wild-type (Wt), and CD1d $d^{-1-}$ (C57BL/6 background) mice, were purchased from

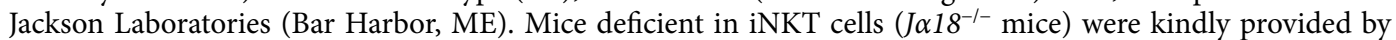
Dr. Taniguchi (Kanagawa, Japan) ${ }^{21}$ and were backcrossed at least 10 times to C57BL/6 (Dr. Thierry Mallevaey, University of Toronto, Canada $)^{52}$.

Measurement of serum iron, transferrin saturation, ALT, and tissue iron concentration. Serum iron, total iron-binding capacity, transferrin saturation, and ALT were assessed via colorimetric assay with the Kodak Ektachem DT60 system (Johnson \& Johnson, Ortho Clinical Diagnostics, Mississauga, ON). Spleen and liver iron concentrations were assessed by acid digestion of tissue samples, followed by iron quantification with atomic absorption spectroscopy ${ }^{53}$.

In vivo activation of iNKT cells. Mice received one injection of $100 \mu \mathrm{g} / \mathrm{kg}$ body weight of $\alpha$-GalCer (Enzo Life Sciences Inc., Farmingdale, NY) diluted in Dulbecco's modified eagle medium (DMEM) (Wisent Inc., StBruno, Québec, Canada). Control mice received a corresponding dose of vehicle.

NK and Kupffer cell depletion. NK cells were depleted by intraperitoneal injection of $500 \mu \mathrm{g}$ anti-asialo GM1 antibody (a-AGM1; Wako Chemicals, Richmond, VA, USA) diluted in PBS, 24 h before a-GalCer treatment. Control mice were injected on the same days with $500 \mu \mathrm{g}$ control rabbit Ig (Jackson ImmunoResearch, West Grove, PA, USA). To deplete Kupffer cells, $200 \mu \mathrm{L}$ of clodronate liposome suspension (c-lip; $5 \mathrm{mg} / \mathrm{ml}$; ClodronateLiposomes.org, Haarlem, The Netherlands) or of PBS encapsulated liposomes (PBS-lip) as control, was injected intravenously into the mice $48 \mathrm{~h}$ before administration of $\mathrm{a}-\mathrm{GalCer}{ }^{54,55}$.

Confirmation of NK and Kupffer cells depletion. Depletion of NK cells was confirmed by analyses of liver mononuclear cells stained with anti-NK1.1 phycoerythrin-conjugated monoclonal antibody (mAb) and anti-CD3 Alexa fluor-conjugated mAb (both from PharMingen, San Diego, CA), followed by flow cytometry as previously described ${ }^{45}$. Samples were analyzed using an LSRFortessa flow cytometer (BD Biosciences) and the data were analyzed using FlowJo software (BD Biosciences).

Kupffer cell depletion was confirmed by quantitative RT-PCR in liver samples using primers for HPRT-1, $\mathrm{F} 4 / 80$ as a representative surface marker of mouse mononuclear phagocytes ${ }^{56}$, and Clec $4 \mathrm{f}$, a specific marker of Kupffer cells ${ }^{57}$.

Measuring iNKT cell proportion and activation following c-lip treatment. Livers were perfused with cold PBS followed by a solution of $1 \mathrm{mg} / \mathrm{ml}$ of collagenase type $\mathrm{V}$ (Sigma). Livers were then harvested, cut into small pieces and incubated with $5 \mathrm{ml}$ of collagenase type $\mathrm{V}$ for $20 \mathrm{~min}$ at $37^{\circ} \mathrm{C}$. The enzymatic digestion was stopped with ice cold media containing $10 \%$ fetal calf serum. The liver was pressed through a $70 \mu \mathrm{m}$ cell strainer. The cell suspension was washed, and lymphocytes were separated on a 33.3\% Percoll density gradient. Spleens were harvested and pressed through a $70 \mu \mathrm{m}$ cell strainer. Both cell suspensions from liver and spleen were treated with an $\mathrm{NH}_{4} \mathrm{Cl}$ solution to lyse red blood cells. Single cell suspensions of liver and spleen were counted on a hemacytometer using trypan blue. To quantify iNKT cells and determine their activation status, cells were stained with the following reagents from Biolegend unless otherwise specified: Viability dye (Zombie Aqua $^{\text {Tu }}$ ), CD45 PerCP-Cy5.5 (RA3-6B2), CD3 BV711 (17A2), CD19 Alexa-Fluor 700 (6D5), PBS57-coupled CD1d tetramer Pacific Blue (NIH tetramer core facility), CD69 APC (H1.2F3), CD335 PE (29A1.4, eBioscience), and NK1.1 BV605 (PK136). The samples were acquired on BD FACSCelesta and analysed with FlowJo LLC software version 10 (BD Biosciences). iNKT cells were defined as CD45 ${ }^{+}$CD19- CD3 ${ }^{+}$CD1d-tetramer ${ }^{+}$ $\mathrm{CD} 335^{-} \mathrm{NK} 1.1^{+}$cells. The percentage of $\mathrm{CD}^{+} 9^{+}$cells among iNKT cells reflects the activation status. Dead cells and doublets were excluded from the analyses.

Measuring immune cell proportion and proliferation following $\alpha$ Gal-Cer treatment. At the indicated time points, single cell suspensions of livers and spleens were prepared as described above. To quantify cell proliferation, cells were stained with the same combination of antibodies used to identify iNKT cells in addition to Ki-67 FITC (B56, BD Biosciences). As a measure of proliferation, the percentage of Ki-67 ${ }^{+}$cells was quantified on total hematopoietic cells $(\mathrm{CD} 45+)$, T cells $\left(\mathrm{CD} 45^{+} \mathrm{CD} 3^{+} \mathrm{CD} 19^{-}\right), \mathrm{B}$ cells $\left(\mathrm{CD} 45^{+} \mathrm{CD} 3^{-} \mathrm{CD} 19^{+}\right)$and iNKT cells $\left(\mathrm{CD} 45^{+} \mathrm{CD} 19^{-} \mathrm{CD} 3^{+} \mathrm{CD} 1 \mathrm{~d}-\right.$ tetramer $\left.^{+} \mathrm{NK} 1.1^{+}\right)$. To quantify TfR expression, cells were stained with the CD71 FITC antibody (C2, BD Biosciences). The samples were acquired on BD FACSCelesta and analysed with FlowJo LLC software version 10 (BD Biosciences). Dead cells and doublets were excluded from the analyses. 
Quantitative RT-PCR. Total RNA was isolated with Trizol reagent (Invitrogen, Burlington, ON), and reverse transcription was performed with the Omniscript RT kit (QIAGEN, Mississauga, ON). mRNA expression levels were measured by real-time PCR in a Rotor Gene 3000 Real Time DNA Detection System (Montreal Biotech, Kirkland, QC) with QuantiTect SYBRGreen I PCR kits (QIAGEN, Mississauga, ON) as previously described $^{53}$. Expression levels were normalized to the housekeeping gene $\beta$-actin $(A c t b)$. Primers are listed in Supplementary Table 1 .

SDS-PAGE and Western blot analysis. SDS-PAGE and western blot analysis were performed on liver nuclear extracts ${ }^{36}$. Livers were removed, rinsed in ice-cold PBS, and used to prepare liver nuclear extracts with Nuclear Extract Kits (Active Motif, Carlsbad, CA). Nuclear protein extracts were separated by 10\% SDS-PAGE gel and blotted onto nitrocellulose membranes (GE Healthcare, Little Chalfont, United Kingdom). The membranes were immunoblotted with the following antibodies: phospho-STAT3, STAT3, phospho-SMAD1/5/8 (Cell Signaling, catalogue \#9511S, Danvers, MA), SMAD1/5/8 (Santa Cruz Biotechnology, catalogue \#SC-6031-R, Santa Cruz, CA) and $\beta$-actin (Abcam, Cambridge, MA). As a secondary antibody, anti-rabbit IgG (Cell Signaling) or anti-mouse IgG (GE Healthcare) were used. Antigen-antibody complexes were visualized with the ECL Western Blotting Detection Reagent (GE Healthcare) in X-ray film. Films were digitalized using a scanner (HP psc2350, 300 dpi resolution), and obtained JPEG images were imported into Adobe Illustrator (300 dpi) and assembled.

Serum and liver ferritin assay. Ferritin was measured with an ELISA kit as per manufacturer's instructions for serum (mouse Ferritin Light chain ELISA kit, Kamiya Biomedical, Seattle, USA) and for liver homogenates (mouse Ferritin Heavy chain ELISA kit, Kamiya Biomedical).

Histology. Liver tissue sections were stained with DAB-enhanced Perl's Prussian blue for ferric iron detection (iron stain kit; Sigma Immunochemicals).

Statistical analysis. All statistics were calculated with Prism software (GraphPad, San Diego, CA), with a pre-specified significant $P$-value of 0.05 . Data were pooled from two or three independent experiments. Multiple comparisons were evaluated statistically by one-way analysis of variance (ANOVA) followed by the Bonferroni multiple comparison test.

Received: 12 May 2020; Accepted: 19 November 2020

Published online: 03 December 2020

\section{References}

1. Weiss, G., Ganz, T. \& Goodnough, L. T. Anemia of inflammation. Blood 133, 40-50. https://doi.org/10.1182/blood-2018-06-85650 0 (2019).

2. Weiss, G. Iron metabolism in the anemia of chronic disease. Biochim. Biophys. Acta 1790, 682-693 (2009).

3. Andrews, N. C. Anemia of inflammation: The cytokine-hepcidin link. J. Clin. Invest 113, 1251-1253 (2004).

4. Hentze, M. W., Muckenthaler, M. U., Galy, B. \& Camaschella, C. Two to tango: Regulation of Mammalian iron metabolism. Cell 142, 24-38. https://doi.org/10.1016/j.cell.2010.06.028 (2010).

5. Park, C. H., Valore, E. V., Waring, A. J. \& Ganz, T. Hepcidin, a urinary antimicrobial peptide synthesized in the liver. J. Biol. Chem. 276, 7806-7810 (2001).

6. Pigeon, C. et al. A new mouse liver-specific gene, encoding a protein homologous to human antimicrobial peptide hepcidin, is overexpressed during iron overload. J. Biol. Chem. 276, 7811-7819 (2001).

7. Kubes, P. \& Jenne, C. Immune responses in the liver. Annu. Rev. Immunol. 36, 247-277. https://doi.org/10.1146/annurev-immun ol-051116-052415 (2018).

8. Eberl, G. et al. Tissue-specific segregation of CD1d-dependent and CD1d-independent NK T cells. J. Immunol. 162, 6410-6419 (1999).

9. Nishimura, T. et al. The interface between innate and acquired immunity: Glycolipid antigen presentation by CD1d-expressing dendritic cells to NKT cells induces the differentiation of antigen-specific cytotoxic T lymphocytes. Int. Immunol. 12, 987-994. https://doi.org/10.1093/intimm/12.7.987 (2000).

10. Matsuda, J. L. et al. Tracking the response of natural killer T cells to a glycolipid antigen using CD1d tetramers. J. Exp. Med. 192, 741-754 (2000).

11. Zeissig, S. et al. CD1d-restricted pathways in hepatocytes control local natural killer T cell homeostasis and hepatic inflammation. Proc. Natl. Acad. Sci. USA 114, 10449-10454. https://doi.org/10.1073/pnas.1701428114 (2017).

12. Huh, J. Y. et al. Deletion of CD1d in adipocytes aggravates adipose tissue inflammation and insulin resistance in obesity. Diabetes 66, 835-847. https://doi.org/10.2337/db16-1122 (2017).

13. Luc, V. K. NKT cells: T lymphocytes with innate effector functions. Curr. Opin. Immunol. 19, 354-364 (2007).

14. Taniguchi, M., Tashiro, T., Dashtsoodol, N., Hongo, N. \& Watarai, H. The specialized iNKT cell system recognizes glycolipid antigens and bridges the innate and acquired immune systems with potential applications for cancer therapy. Int. Immunol. 22, 1-6. https://doi.org/10.1093/intimm/dxp104 (2010).

15. Choi, J., Rudak, P. T., Lesage, S. \& Haeryfar, S. M. M. Glycolipid stimulation of invariant NKT cells expands a unique tissue-resident population of precursors to mature NK Cells endowed with oncolytic and antimetastatic properties. J. Immunol. 203, 1808-1819. https://doi.org/10.4049/jimmunol.1900487 (2019).

16. De Domenico, I. et al. Hepcidin mediates transcriptional changes that modulate acute cytokine-induced inflammatory responses in mice. J. Clin. Invest. 120, 2395-2405 (2010).

17. Natori, T., Morita, M., Akimoto, K. \& Koezuka, Y. Agelasphins, novel antitumor and immunostimulatory cerebrosides from the marine sponge Agelas mauritianus. Tetrahedron 50, 2771-2784. https://doi.org/10.1016/S0040-4020(01)86991-X (1994).

18. Eberl, G. \& MacDonald, H. R. Selective induction of NK cell proliferation and cytotoxicity by activated NKT cells. Eur. J. Immunol. 30, 985-992. https://doi.org/10.1002/(sici)1521-4141(200004)30:4\%3c985::aid-immu985\%3e3.0.co;2-e (2000). 
19. Eberl, G., Brawand, P. \& MacDonald, H. R. Selective bystander proliferation of memory $\mathrm{CD}^{+}$and $\mathrm{CD} 8^{+} \mathrm{T}$ cells upon NK T or T cell activation. J. Immunol. 165, 4305-4311. https://doi.org/10.4049/jimmunol.165.8.4305 (2000).

20. Bendelac, A. et al. CD1 recognition by mouse NK1+ T lymphocytes. Science 268, 863-865 (1995).

21. Cui, J. et al. Requirement for Va14 NKT cells in IL-12-mediated rejection of tumors. Science 278, 1623-1626. https://doi. org/10.1126/science.278.5343.1623 (1997).

22. Carnaud, C. et al. Cutting edge: Cross-talk between cells of the innate immune system: NKT cells rapidly activate NK cells. J. Immunol. 163, 4647-4650 (1999).

23. Kasai, M. et al. In vivo effect of anti-asialo GM1 antibody on natural killer activity. Nature 291, 334-335. https://doi. org/10.1038/291334a0 (1981).

24. Decker, K. Biologically active products of stimulated liver macrophages (Kupffer cells). Eur. J. Biochem. 192, 245-261. https://doi. org/10.1111/j.1432-1033.1990.tb19222.x (1990).

25. Nemeth, E. et al. IL-6 mediates hypoferremia of inflammation by inducing the synthesis of the iron regulatory hormone hepcidin. J. Clin. Invest. 113, 1271-1276. https://doi.org/10.1172/JCI20945 (2004).

26. Osman, Y. et al. Activation of hepatic NKT cells and subsequent liver injury following administration of $a$-galactosylceramide. Eur. J. Immunol. 30, 1919-1928. https://doi.org/10.1002/1521-4141(200007)30:7\%3c1919::Aid-immu1919\%3e3.0.Co;2-3 (2000).

27. Babitt, J. L. et al. Bone morphogenetic protein signaling by hemojuvelin regulates hepcidin expression. Nat. Genet. 38, 531-539 (2006).

28. Andriopoulos, B. Jr. et al. BMP6 is a key endogenous regulator of hepcidin expression and iron metabolism. Nat. Genet. 41, 482-487. https://doi.org/10.1038/ng.335 (2009).

29. Corradini, E. et al. Serum and liver iron differently regulate the bone morphogenetic protein 6 (BMP6)-SMAD signaling pathway in mice. Hepatology (Baltimore, MD) 54, 273-284. https://doi.org/10.1002/hep.24359 (2011).

30. Kautz, L. et al. Iron overload induces BMP6 expression in the liver but not in the duodenum. Haematologica 96, 199-203. https:// doi.org/10.3324/haematol.2010.031963 (2011).

31. Mleczko-Sanecka, K. et al. SMAD7 controls iron metabolism as a potent inhibitor of hepcidin expression. Blood 115, 2657-2665. https://doi.org/10.1182/blood-2009-09-238105 (2010).

32. Wrighting, D. M. \& Andrews, N. C. Interleukin-6 induces hepcidin expression through STAT3. Blood 108, 3204-3209. https:// doi.org/10.1182/blood-2006-06-027631 (2006).

33. Puig, S., Ramos-Alonso, L., Romero, A. M. \& Martínez-Pastor, M. T. The elemental role of iron in DNA synthesis and repair. Metallomics 9, 1483-1500. https://doi.org/10.1039/C7MT00116A (2017).

34. Nemeth, E. et al. Hepcidin regulates cellular iron efflux by binding to ferroportin and inducing its internalization. Science 306, 2090-2093. https://doi.org/10.1126/science.1104742 (2004).

35. Papanikolaou, G. \& Pantopoulos, K. Systemic iron homeostasis and erythropoiesis. IUBMB Life 69, 399-413. https://doi. org/10.1002/iub.1629 (2017).

36. Huang, H., Constante, M., Layoun, A. \& Santos, M. M. Contribution of STAT3 and SMAD4 pathways to the regulation of hepcidin by opposing stimuli. Blood 113, 3593-3599. https://doi.org/10.1182/blood-2008-08-173641 (2009).

37. Maia, M. L. et al. Invariant natural killer T cells are reduced in hereditary hemochromatosis patients. J. Clin. Immunol. 35, 68-74. https://doi.org/10.1007/s10875-014-0118-0 (2015).

38. Sukhbaatar, N. \& Weichhart, T. Iron regulation: Macrophages in control. Pharmaceuticals 11, 137 (2018).

39. Theurl, M. et al. Kupffer cells modulate iron homeostasis in mice via regulation of hepcidin expression. J. Mol. Med. 86, 825. https ://doi.org/10.1007/s00109-008-0346-y (2008).

40. Lou, D.-Q. et al. Iron- and inflammation-induced hepcidin gene expression in mice is not mediated by Kupffer cells in vivo. Hepatology (Baltimore, MD) 41, 1056-1064. https://doi.org/10.1002/hep.20663 (2005).

41. Montosi, G. et al. Kupffer cells and macrophages are not required for hepatic hepcidin activation during iron overload. Hepatology (Baltimore, MD) 41, 545-552. https://doi.org/10.1002/hep.20620 (2005).

42. Falzacappa, M. V. V. et al. STAT3 mediates hepatic hepcidin expression and its inflammatory stimulation. Blood 109, 353-358. https://doi.org/10.1182/blood-2006-07-033969 (2007).

43. Cao, Z. et al. A critical role for IFN regulatory factor 1 in NKT cell-mediated liver injury induced by a-galactosylceramide. J. Immunol. 185, 2536-2543. https://doi.org/10.4049/jimmunol.1000092 (2010).

44. Bendelac, A., Savage, P. B. \& Teyton, L. The biology of NKT cells. Annu. Rev. Immunol. 25, 297-336 (2007).

45. Makui, H., Soares, R. J., Jiang, W., Constante, M. \& Santos, M. M. Contribution of Hfe expression in macrophages to the regulation of hepatic hepcidin levels and iron loading. Blood 106, 2189-2195 (2005).

46. Mazur, A. et al. Dietary iron regulates hepatic hepcidin 1 and 2 mRNAs in mice. Metabolism 52, 1229-1231. https://doi.org/10.1016/ S0026-0495(03)00277-4 (2003).

47. Kautz, L. et al. Iron regulates phosphorylation of Smad1/5/8 and gene expression of Bmp6, Smad 7, Id1, and Atoh8 in the mouse liver. Blood 112, 1503-1509. https://doi.org/10.1182/blood-2008-03-143354 (2008).

48. Wang, R. H. et al. A role of SMAD4 in iron metabolism through the positive regulation of hepcidin expression. Cell Metab. 2, 399-409. https://doi.org/10.1016/j.cmet.2005.10.010 (2005).

49. Casanovas, G., Mleczko-Sanecka, K., Altamura, S., Hentze, M. W. \& Muckenthaler, M. U. Bone morphogenetic protein (BMP)responsive elements located in the proximal and distal hepcidin promoter are critical for its response to HJV/BMP/SMAD. J. Mol. Med. 87, 471-480. https://doi.org/10.1007/s00109-009-0447-2 (2009).

50. Zhang, Z. et al. Bmp6 expression can be regulated independently of liver iron in mice. PLoS ONE 9, e84906. https://doi.org/10.1371/ journal.pone.0084906 (2014).

51. Seligman, P. A., Kovar, J. \& Gelfand, E. W. Lymphocyte proliferation is controlled by both iron availability and regulation of iron uptake pathways. Pathobiology 60, 19-26. https://doi.org/10.1159/000163692 (1992).

52. Mallevaey, T. et al. Invariant and noninvariant natural killer T cells exert opposite regulatory functions on the immune response during murine schistosomiasis. Infect. Immun. 75, 2171-2180. https://doi.org/10.1128/iai.01178-06 (2007).

53. Layoun, A., Samba-Mondonga, M., Fragoso, G., Calve, A. \& Santos, M. M. MyD88 adaptor protein is required for appropriate hepcidin induction in response to dietary iron overload in mice. Front. Physiol. 9, 159. https://doi.org/10.3389/fphys.2018.00159 (2018).

54. Van Rooijen, N., Kors, N., Ende, M. V. D. \& Dijkstra, C. D. Depletion and repopulation of macrophages in spleen and liver of rat after intravenous treatment with liposome-encapsulated dichloromethylene diphosphonate. Cell Tissue Res. 260, 215-222. https ://doi.org/10.1007/BF00318625 (1990).

55. Yamamoto, T. et al. Repopulation of murine Kupffer cells after intravenous administration of liposome-encapsulated dichloromethylene diphosphonate. Am. J. Pathol. 149, 1271-1286 (1996).

56. Austyn, J. M. \& Gordon, S. F4/80, a monoclonal antibody directed specifically against the mouse macrophage. Eur. J. Immunol. 11, 805-815. https://doi.org/10.1002/eji.1830111013 (1981).

57. Yang, C.-Y. et al. CLEC4F is an inducible C-type lectin in F4/80-positive cells and is involved in alpha-galactosylceramide presentation in liver. PLoS ONE 8, e65070. https://doi.org/10.1371/journal.pone.0065070 (2013). 


\section{Acknowledgements}

This work was supported by grants from the Canadian Institutes of Health Research (CIHR, Grant no. PJT159775) and Natural Sciences and Engineering Research Council of Canada (NSERC, Grant RGPIN-201806442) to MMS. HH received a PhD scholarship from the NSERC. SL is a Research Scholars Emeritus awardee from the FRQS. We wish to thank Dr. Taniguchi (Kanagawa, Japan) and Dr. Thierry Mallevaey (University of Toronto, Canada) for providing us with $J \alpha 18^{-/-}$mice. We also thank Dr. Mary Stevenson for a critical review of the manuscript prior to submission. We thank Jacqueline Chung for editing the manuscript.

\section{Author contributions}

H.H., V.Z.L., G.F., A.C., T.A.H., M.O., G.C.R., V.M.D. and M.M.S. contributed to the investigation, validation, methodology, and formal analysis. H.H. and M.M.S. contributed to conceptualization, data visualization and supervision. V.Z.L., S.L. and M.M.S. reviewed and edited the original draft. M.M.S. additionally contributed to resources and funding acquisition of the study. All authors have read and approved the version to be published.

\section{Competing interests}

The authors declare no competing interests.

\section{Additional information}

Supplementary information is available for this paper at https://doi.org/10.1038/s41598-020-78037-3.

Correspondence and requests for materials should be addressed to M.M.S.

Reprints and permissions information is available at www.nature.com/reprints.

Publisher's note Springer Nature remains neutral with regard to jurisdictional claims in published maps and institutional affiliations.

(c) (i) Open Access This article is licensed under a Creative Commons Attribution 4.0 International License, which permits use, sharing, adaptation, distribution and reproduction in any medium or format, as long as you give appropriate credit to the original author(s) and the source, provide a link to the Creative Commons licence, and indicate if changes were made. The images or other third party material in this article are included in the article's Creative Commons licence, unless indicated otherwise in a credit line to the material. If material is not included in the article's Creative Commons licence and your intended use is not permitted by statutory regulation or exceeds the permitted use, you will need to obtain permission directly from the copyright holder. To view a copy of this licence, visit http://creativecommons.org/licenses/by/4.0/.

(c) The Author(s) 2020 